BANCA D'ITALIA

E U R O S I S T E M A

Questioni di Economia e Finanza

(Occasional Papers)

Indicators of financial vulnerability:

a household level study

by Valentina Miehelangeli and Cristiana Rampazzi 



\section{Questioni di Economia e Finanza}

(Occasional papers)

Indicators of financial vulnerability:

a household level study

by Valentina Michelangeli and Cristiana Rampazzi

Number 369 - December 2016 
The series Occasional Papers presents studies and documents on issues pertaining to the institutional tasks of the Bank of Italy and the Eurosystem. The Occasional Papers appear alongside the Working Papers series which are specifically aimed at providing original contributions to economic research.

The Occasional Papers include studies conducted within the Bank of Italy, sometimes in cooperation with the Eurosystem or other institutions. The views expressed in the studies are those of the authors and do not involve the responsibility of the institutions to which they belong.

The series is available online at www.bancaditalia.it.

ISSN $1972-6627$ (print)

ISSN 1972-6643 (online)

Printed by the Printing and Publishing Division of the Bank of Italy 


\title{
INDICATORS OF FINANCIAL VULNERABILITY: A HOUSEHOLD LEVEL STUDY
}

\author{
by Valentina Michelangeli* and Cristiana Rampazzi*
}

\begin{abstract}
This paper compares two indicators of household vulnerability using the Bank of Italy's Survey on Household Income and Wealth (2008-2014). According to the first indicator, a household is considered vulnerable if its debt service-to-income ratio exceeds 30 per cent and its income is below the median of the population. According to the second, a household is defined vulnerable if the sum of its income and liquid financial assets is not sufficient to cover debt payments and basic living costs for four months. While providing similar information on the proportion of households deemed vulnerable, the two indicators capture different aspects of the sector's financial fragility: vulnerable households according to the first indicator have, on average, higher income, liquid assets and debt than those identified by the second indicator. Moreover, while the first indicator shows a lower correlation with payment arrears, its simplicity, timeliness and less arbitrary components make it better suited for cross-country comparisons.
\end{abstract}

JEL Classification: D12, I32

Keywords: household vulnerability, debt service, financial margin.

\section{Contents}

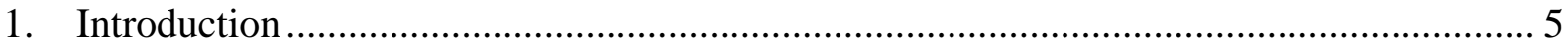

2. Description of the two indicators of financial vulnerability ............................................ 6

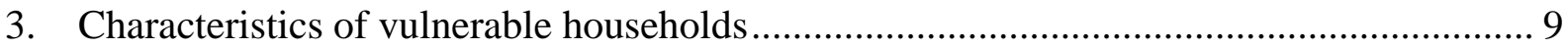

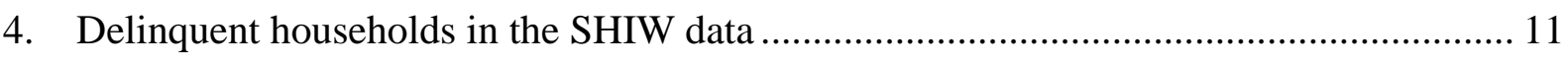

5. Contemporaneous relationship between vulnerable and delinquent households .............. 11

6. Performance of the two indicators in predicting delinquent households ......................... 13

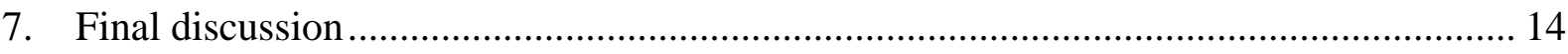

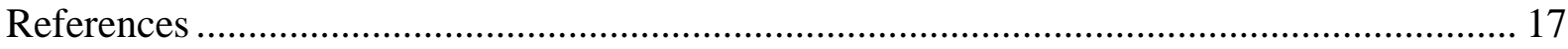

\footnotetext{
* Bank of Italy, Financial Stability Directorate.
} 



\section{Introduction ${ }^{1}$}

Monitoring the financial health of indebted households is important for at least two reasons. First, households' inability to pay their debt in a timely manner may have negative effects on banks' balance sheets. An increase in loan arrears, by affecting banks' asset quality and profitability, can generate financial instability. Second, high levels of indebtedness make households more sensitive to economic shocks (Debelle, 2004) and the run-up in households' debt typically anticipates financial crises (Brown et al., 2010; Bunn and Romstom, 2015, among others).

The recent availability of detailed microeconomic data allows us to identify which type of household is most exposed to the risk of delaying debt payments and to evaluate the distribution of vulnerabilities across the population. This could help to direct an analysis of the drivers of the risks and to identify policy measures for helping distressed households.

Several central banks have developed indicators of households' financial fragility based on granular data. Among the standard indicators of households' vulnerability are the debt-to-income ratio, the debt-toasset ratio and the debt service-to-income ratio (ECB, 2004; Bank of Spain, 2008; Bank of England, 2016, among others), which display substantial differences across countries (HFCN, 2013). Indeed, a single metric may be not sufficient to fully describe the fragilities of the household sector and it may need to be revised over time. The aim of this brief paper is to compare two more detailed indicators recently proposed in the literature. According to the first indicator, a household is considered vulnerable if its debt service-toincome ratio is above 30 per cent and its income is below the median of the population (Bank of Italy, 2012). According to the second indicator, a household is considered vulnerable if the sum of its net income and liquid financial assets is not sufficient to cover debt payments and basic living costs for a given number of months (Ampudia et al., 2016). In this work we try to answer the following questions. 1) Do the two indicators of vulnerability identify the same set of households? 2) Are the two indicators correlated with households' delinquency, defined as a delay in debt payments?

Many scholars have studied the relationship between vulnerability indicators and households' debt payment problems. However, some papers have only used aggregate data (Vatne, 2006), while others have only referred to the pre-crisis period (May and Tudela, 2005; Beer and Schurz, 2007; Karasulu, 2008, among others) or to mortgage debt (Dey et al., 2008; Vacca et al., 2013, among others). We contribute to this literature by employing microeconomic data on any household debt payment (mortgage, consumer credit and others) to construct the vulnerability indicators and by evaluating how these metrics relate to late household payments during and after the financial crisis. Furthermore, by exploiting the panel dimension of our data, we can also evaluate the two-year-ahead forecast ability of the indicators.

Both the indicators considered in this paper have advantages and disadvantages. The first metric (based on the debt service-to-income ratio) is very simple to compute and enables comparisons across time and countries; on the other hand, it does not take account of the use of household savings to cover debt expenses. The second one has the advantage of also considering household asset holdings; on the other hand, it displays elements of arbitrariness in the computation of some of its components, which could vary notably over time and across countries.

\footnotetext{
${ }^{1}$ We thank F. Columba, P. Finaldi Russo, G. Gobbi, S. Magri, M. Tasso, and V. Vacca for their useful comments. The analysis and conclusions expressed herein are those of the authors and should not be attributed to the Bank of Italy.
} 
In our exercise we exploit four waves (2008, 2010, 2012 and 2014) from the Bank of Italy's Survey on Household Income and Wealth (SHIW) that contain detailed information on Italian households' late payments, mortgages, consumer credit and other debts, in addition to demographic and financial variables. We find that 1 ) the two indicators identify quite different types of households: the ones classified as vulnerable according to the metric based on the debt service-to-income ratio have on average a higher income and hold more debt than the ones classified as vulnerable according to the other indicator; 2) households classified as vulnerable according to either indicator are more likely to be delinquent in their debt payments. Combining both indicators into a third one yields a better outcome than using the two indicators separately in terms of a correct identification of households that are late with their payments. Indeed, the share of truly delinquent households correctly classified exceeds 60 per cent (30 per cent and 54 per cent respectively for the two individual metrics). Also the two-year-ahead forecast ability of the combined indicator is markedly better than that of each indicator alone. All the indicators tend to overpredict households with late payments, thereby providing an upper bound on the risk stemming from the household sector.

The paper is organized as follows. The second section presents the two vulnerability indicators. The third section describes the characteristics of vulnerable households. The fourth section focuses on delinquent households in the SHIW data. The fifth section presents evidence of the contemporaneous relationship between vulnerable and delinquent households, while the sixth section analyses the performance of the two indicators in predicting delinquent households in two years' time. The seventh section provides a final discussion.

\section{Description of the two indicators of financial vulnerability}

The debt service-to-income ratio is a commonly used indicator of financial vulnerability (Bank of Canada, 2011; Bank of England, 2014; Bank of Italy, 2012; ECB, 2014, among others). It is defined as the share of household disposable income that is devoted to service debt. High debt service does not only affect a household's ability to meet its debt obligations, but also the lender's decision to grant more credit and thus the household's capacity to smooth consumption over time. The advantages of this indicator are that it does not present elements of arbitrariness in the computation of its components (debt instalments and disposable income) and that it lends itself well to a comparison over time and across countries. One challenge, however, is correctly identifying the threshold beyond which households are classified as vulnerable. Some scholars have analysed how debt delinquency changes for different threshold values. Among works that have only considered mortgage debt, May and Tudela (2005) and Tiongson et al. (2009) have selected a 20 per cent threshold, while Dey et al. (2008) using a sample over the period 1999-2006 detected a critical threshold at 35 per cent. Other studies (Beer and Schurz, 2007; ECB, 2007; Karasulu, 2008), considering total household debt, have favoured a threshold of 30 per cent. Vacca et al. (2013), using the 2007-2009 EU-SILC data and focusing only on households with mortgage debt, confirmed that the risk of arrears increases at a 30 per cent threshold and for households whose income net of debt payments is below the relative poverty line. Following this latter study and in line with previous Bank of Italy publications (Bank of Italy, 2012, 2013, 2014, among others), we define a household as vulnerable if its debt service-to-income ratio exceeds 30 per cent and its income is below the median of the population. This second condition accounts for the fact that negative economic shocks typically have a more adverse effect on the financial position of low-income households than on that of high-income ones. This indicator, 
in short the DSIMI (debt service-to-income ratio median income indicator), takes a value of one if the following two conditions are satisfied and zero otherwise: ${ }^{2}$

$$
\frac{\text { debt payments }}{\text { net income }}>30 \%
$$

and

$$
\text { net equalized income < median net equalized income }
$$

The financial margin is defined as the net income available to households after debt payments and basic living expenses. It has been extensively studied in the literature (IMF, 2005; Johansson and Persson, 2006; Stone, 2006; Vatne, 2006; Zajączkowski and Żochowski, 2007) and it relies on the idea that households with a negative financial margin are more likely to be delinquent than others. Ampudia et al. (2016) augmented this indicator to take into account both the solvency and the liquidity position of households. Specifically, a household is considered vulnerable if the sum of its net income and liquid financial assets ${ }^{3}$ is not sufficient to cover debt payments and basic living costs. ${ }^{4}$ This implies that even a household with a negative financial margin may be not vulnerable if its liquid assets are enough to cover its expenses over a given number of months. This augmented indicator, denoted as the FMLAI (financial margin liquid assets indicator), takes a value of one if the following two conditions are satisfied and zero otherwise:

$$
\begin{gathered}
\text { financial margin }=\text { net income }- \text { debt payments }- \text { basic living costs }<0 \\
\text { and } \\
\mid \text { financial margin } \mid * \text { number of months }>\text { liquid financial assets }
\end{gathered}
$$

The FMLAI presents more elements of arbitrariness in the computation of its components than the DSIMI. First, basic living costs may correspond to a constant fraction of the median income and be assumed as identical for all households. Alternatively, they can be set equal to an estimate based on each household's subjective assessment of minimum consumption and thus differ across all families. In this exercise, we set the basic living costs equal to 40 per cent of the median income, which corresponds to the lower threshold of the poverty line as defined by the European Commission (2011), adjusted by the number of members of each household.

Second, the number of months may be chosen on the basis of either macro or micro data. Ampudia et al. (2016) used macro data as individual information on households' late payments was not available in the Household Finance and Consumption Survey (HFCS). Specifically, they calibrated the number of months to be used in the definition of the indicator using data on each euro-area country's stock of non-performing

\footnotetext{
2 In the definition of the DSIMI, net income reflects households' disposable income gross of financial charges and net of imputed rent. Net equalized income is total household income adjusted to obtain a representative income using the OECD modified scale, which assigns a value of 1 to the household head, 0.5 to each additional adult member and 0.3 to each child. See Michelangeli and Pietrunti (2014) for a detailed description of the indicator.

${ }^{3}$ Liquid financial assets include deposits, bonds, mutual funds, stocks, and managed accounts.

${ }^{4}$ For tenants we also subtract rent paid from the financial margin.
} 
loans to total loans of the household sector (NPL) in $2010 .^{5}$ As a result, they set the number of months equal to 3.9 for Italy, but the range goes from 0 for Spain and Cyprus to 25.9 for Austria. Then, as the share of vulnerable households depends on the actual share of non-performing loans in the reference year, the ability to correctly identify distressed households is high in that year by construction. However, the indicator's out-of-sample performance could be debatable because a change in the financial conditions that affects the country's share of non-performing loans may lead to a review of the parameter value in subsequent years. Furthermore, as the identified range for the number of months is quite wide, the FMLAI's comparability across countries could be limited.

To calibrate the number of months we exploit the SHIW time series dimension and the information on households' late payments. Considering the same range of months identified by Ampudia et al. (2016), we first compute for any number of months the associated share of vulnerable households in each year 2008, 2010, 2012, and 2014. We then evaluate, again for any number of months, the correlation between the average share of delinquent and vulnerable households. As shown in Figure 1, the correlation takes the highest values for a number of months between two and four, which means that on average Italian households with a negative financial margin hold enough liquidity to avoid distress for two/four months. Thus, in line with Ampudia et al. (2016), in the rest of the paper we set the number of months equal to four. Robustness tests show that small modifications in the number of months do not alter our main conclusions.

Figure 1: Correlation between the share of vulnerable and delinquent households

(percentages across number of months)

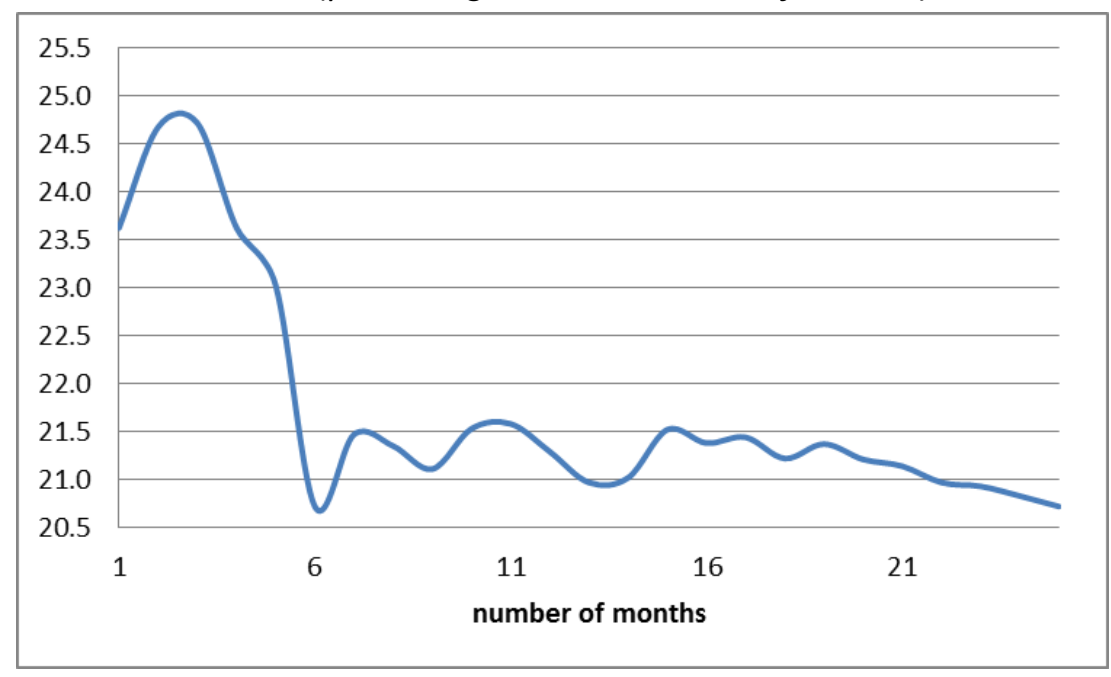

Note: A change in the number of months in equation (2) affects the share of households identified as vulnerable according to the FMLAI. The figure shows the contemporaneous correlation between the average share of delinquent and vulnerable households by number of months over the period 2008-14 in Italy.

\footnotetext{
${ }^{5}$ The number of months affects the share of vulnerable households and it is chosen to minimize the difference between the ratio of non-performing loans to total loans and the share of debt held by vulnerable households for each country in 2009-10, the HFCS's reference years. For example, in Italy the number of months is set at 3.9 so that the resulting share of debt held by vulnerable households, equal to 7.2 per cent, corresponds to the ratio of nonperforming loans to total loans for the mortgage market in 2010. Harmonized data on non-performing loans across European countries were firstly published by the EBA in 2015 and readjusted by Ampudia et al. (2016) to obtain a value for 2010 .
} 


\section{Characteristics of vulnerable households}

In this section we evaluate the characteristics of vulnerable households as defined according to the DSIMI and the FMLAI and we study whether the two indicators identify the same group of households. As the SHIW questions on late payments, on consumer credit and on other debt payments were only introduced in 2008, we restricted our analysis to the four most recent waves (2008, 2010, 2012 and 2014). The total sample consists of 5,996 indebted households.

The shares of households classified as vulnerable according to the two indicators, together with the share of debt held by these families, are reported in Table 1. As shown in Panel a), households identified by the DSIMI and the FMLAI as vulnerable are respectively 12.6 and 14.1 per cent across the four waves. However, even though the total share of indebted households in the population is about the same, the two indicators select quite different households: indeed, those that are vulnerable according to both indicators are only about one third of those classified according to either one or the other (6.6 versus 20.0 per cent). Panel b) shows the share of debt held by vulnerable households: unlike the previous statistic, in each year the ratio is larger for households considered vulnerable according to the DSIMI.

Table 1: Vulnerable households for each indicator of financial vulnerability (indebted households only)

a) Share of vulnerable households (percentages)

\begin{tabular}{ccccc}
\hline & DSIMI & FMLAI & DSIMI or FMLAI & DSIMI and FMLAI \\
\hline 2008 & 12.9 & 14.6 & 20.4 & 7.2 \\
2010 & 11.5 & 15.7 & 20.4 & 6.8 \\
2012 & 14.0 & 14.0 & 21.5 & 6.5 \\
2014 & 11.7 & 11.7 & 17.6 & 5.8 \\
Average & 12.6 & 14.1 & 20.0 & 6.6 \\
\hline
\end{tabular}

b) Share of debt held by vulnerable households (percentages)

\begin{tabular}{ccccc}
\hline & DSIMI & FMLAI & DSIMI or FMLAI & DSIMI and FMLAI \\
\hline 2008 & 24.3 & 17.0 & 27.5 & 13.7 \\
2010 & 16.5 & 12.9 & 19.7 & 9.8 \\
2012 & 18.6 & 11.5 & 22.6 & 7.5 \\
2014 & 16.8 & 9.7 & 18.7 & 7.8 \\
Average & 19.1 & 12.8 & 22.2 & 9.7 \\
\hline
\end{tabular}

Table 2 shows which characteristics are more important in discriminating across the two groups. On average, vulnerable households according to the DSIMI are richer: 56 per cent per cent of them belong to the first quartile of equalized income (more than 90 per cent for those vulnerable according to the FMLAI) and their average income is almost twice that of the other group. They also have more financial assets: 41 per cent of them belong to the first quartile (more than 80 per cent for those vulnerable according to the FMLAI). Their average amount of total debt is about three times that of the other group and they tend to be concentrated in the upper debt quartiles. In our sample, as their debt service-to-income ratio is above 30 per cent, all of them belong to the fourth quartile of debt service-to-income ratio (only 51 per cent for those vulnerable according to the FMLAI). Differences across the two groups are statistically significant also with respect to working status and geographic area. 
Table 2: Characteristics of vulnerable households

\begin{tabular}{|c|c|c|c|}
\hline & DSIMI & FMLAI & $\begin{array}{l}\text { Significativity } \\
\text { of differences }\end{array}$ \\
\hline \multicolumn{4}{|l|}{ Average values } \\
\hline Age & 44 & 45 & \\
\hline Income $(€)$ & 10,085 & 6,380 & $* * *$ \\
\hline Financial assets $(€)$ & 4,299 & 596 & *** \\
\hline Total debt $(€)$ & 69,697 & 25,008 & $* * *$ \\
\hline Net wealth $(€)$ & 114,894 & 54,409 & $* * *$ \\
\hline \multicolumn{4}{|c|}{ Distribution (Share of households, percentages) } \\
\hline \multicolumn{4}{|c|}{ Household's age class } \\
\hline$<35$ & 18.8 & 19.8 & \\
\hline $35-44$ & 37.6 & 32.1 & * \\
\hline $45-54$ & 28.1 & 27.9 & \\
\hline $55-64$ & 10.3 & 11.8 & \\
\hline$>=65$ & 5.3 & 8.4 & $* * *$ \\
\hline \multicolumn{4}{|l|}{ Working status } \\
\hline Employee & 62.9 & 66.1 & \\
\hline Self-employed & 20.6 & 10.6 & *** \\
\hline Not employed & 16.4 & 23.4 & $* * *$ \\
\hline \multicolumn{4}{|l|}{ Geographic area } \\
\hline North & 41.9 & 28.8 & $* * *$ \\
\hline Centre & 19.3 & 10.4 & *** \\
\hline South and Islands & 38.7 & 60.8 & $* * *$ \\
\hline \multicolumn{4}{|c|}{ Equalized income quartile (1) } \\
\hline $1^{\circ}$ & 55.7 & 91.3 & $* * *$ \\
\hline $2^{\circ}$ & 44.2 & 8.3 & $* * *$ \\
\hline $3^{\circ}$ & 0.0 & 0.0 & \\
\hline $4^{\circ}$ & 0.0 & 0.0 & \\
\hline \multicolumn{4}{|c|}{ Financial assets quartile (1) } \\
\hline $1^{\circ}$ & 40.8 & 82.2 & $* * *$ \\
\hline $2^{\circ}$ & 37.1 & 16.2 & *** \\
\hline $3^{\circ}$ & 17.6 & 1.6 & *** \\
\hline $4^{\circ}$ & 4.4 & 0.4 & *** \\
\hline \multicolumn{4}{|l|}{ Debt quartile (2) } \\
\hline $1^{\circ}$ & 9.3 & 29.8 & $* * *$ \\
\hline $2^{\circ}$ & 15.8 & 26.6 & $* * *$ \\
\hline $3^{\circ}$ & 32.1 & 21.6 & $* * *$ \\
\hline $4^{\circ}$ & 42.8 & 22.0 & $* * *$ \\
\hline \multicolumn{4}{|c|}{ Debt service-to-income ratio quartile (2) } \\
\hline$<0.08$ & 0.0 & 15.0 & $* * *$ \\
\hline $0.08-0.17$ & 0.0 & 12.9 & *** \\
\hline $0.17-0.27$ & 0.0 & 21.2 & $* * *$ \\
\hline$>=0.27$ & 100.0 & 50.9 & $* * *$ \\
\hline \multicolumn{4}{|c|}{ Net wealth quartile (1) } \\
\hline $1^{\circ}$ & 22.5 & 49.6 & *** \\
\hline $2^{\circ}$ & 51.1 & 35.9 & $* * *$ \\
\hline $3^{\circ}$ & 17.2 & 11.3 & $* * *$ \\
\hline $4^{\circ}$ & 9.2 & 3.2 & $* * *$ \\
\hline
\end{tabular}

Statistical significance: ${ }^{*} p<0.05{ }^{* *} p<0.01{ }^{* * *} p<0.001$

(1) Quartiles refer to total sample. (2) Quartiles refer to indebted households only. 


\section{Delinquent households in the SHIW data}

Our next goal is to evaluate the strength of the correlation of both indicators with the incidence of households that are late with payments. We therefore exploit the following SHIW question: 'Considering all loans of whatever type, was the household behind with payments by more than 90 days at any time or for any period of time last year?'

In our sample, delinquent households are about 5 per cent of the indebted ones and hold about 4.5 per cent of the total debt of the household sector. As shown in Table 3, these families mostly belong to the first quartile of equalized income and financial assets, but a non-negligible share can be found in the upper quartiles. With respect to debt holdings, delinquent households are about equally distributed, while only about 40 per cent of them belong to the upper debt service-to-income quartile (i.e. have a debt service-toincome ratio above 27 per cent). Almost 70 per cent of them can be found in the first two quartiles of net wealth. About 63 per cent of household heads are employees, while the remainder are about equally split between self-employed and not employed. The great majority of delinquent households live in the North (48 per cent), followed by households living in the South and Islands ( 35 per cent) and in the Centre (17 per cent).

Table 3: Distribution of 90+ days delinquent households (percentages)

\begin{tabular}{cccccc}
\hline quartiles & $\begin{array}{c}\text { Equalized } \\
\text { income (1) }\end{array}$ & $\begin{array}{c}\text { Financial assets } \\
\mathbf{( 1 )}\end{array}$ & $\begin{array}{c}\text { Total debt } \\
\mathbf{( 2 )}\end{array}$ & $\begin{array}{c}\text { Debt service-to- } \\
\text { income ratio (2) }\end{array}$ & $\begin{array}{c}\text { Net wealth } \\
\text { quartile (1) }\end{array}$ \\
\hline $1^{\circ}$ & 53.9 & 55.4 & 23.2 & 17.6 & 38.4 \\
$2^{\circ}$ & 20.7 & 25.8 & 29.2 & 19.0 & 30.6 \\
$3^{\circ}$ & 17.4 & 12.7 & 27.1 & 22.4 & 18.4 \\
$4^{\circ}$ & 8.1 & 6.1 & 20.4 & 41.1 & 12.7 \\
\hline
\end{tabular}

(1) Quartiles refer to total sample.

(2) Quartiles refer to indebted households only.

\section{Contemporaneous relationship between vulnerable and delinquent households}

We now test whether the two indicators correlate with households' late payments. To this end, we run the following regression:

$$
\operatorname{Pr}\left(\text { delinquency }_{t}\right)=D\left(\text { vuln }_{t}\right)+\varepsilon_{t}
$$

where delinquency ${ }_{t}$ takes a value equal to 1 if the household declares itself to be behind with payments by more than 90 days and zero otherwise. The variable $D\left(v u l n_{t}\right)$ is a dummy equal to one if the household is classified as vulnerable at time $t$. The results of the logit regressions are shown in Table 4, which also reports the percentage of correctly predicted cases (the share of households that are classified correctly, delinquent or non-delinquent), the sensitivity (the share of delinquent households that are classified correctly), the specificity (the share of non-delinquent households that are classified correctly), the false positive rate (the share of households that are erroneously predicted as delinquent), and the false negative rate (the share of households that are erroneously predicted as non-delinquent). 
Table 4: Logit regressions: probability of delinquency (contemporaneous relationship)

\begin{tabular}{|c|c|c|c|}
\hline & (1) & (2) & (3) \\
\hline vuln DSIMI (t) & $\begin{array}{l}0.08302 \text { *** } \\
(0.01698)\end{array}$ & & \\
\hline vuln FMLAI (t) & & $\begin{array}{l}0.148108^{* \star \star} \\
(0.01778)\end{array}$ & \\
\hline vuln DSIMI (t) or vuln FMLAI (t) & & & $\begin{array}{c}0.11757^{\text {*** }} \\
(0.01391)\end{array}$ \\
\hline Observations & 5,995 & 5,995 & 5,995 \\
\hline$F(1,5994)$ & 45.33 & 140.41 & 119.58 \\
\hline Correctly predicted & $86.6 \%$ & $86.8 \%$ & $82.1 \%$ \\
\hline Sensitivity & $29.9 \%$ & $54.2 \%$ & $61.5 \%$ \\
\hline Specificity & $89.6 \%$ & $88.5 \%$ & $83.2 \%$ \\
\hline False + rate for true & $10.4 \%$ & $11.5 \%$ & $16.8 \%$ \\
\hline False - rate for true & $70.1 \%$ & $45.8 \%$ & $38.5 \%$ \\
\hline Average default probab. (predicted) & $4.6 \%$ & $3.8 \%$ & $3.8 \%$ \\
\hline
\end{tabular}

The table reports marginal effects.

Standard errors in parentheses.

Statistical significance: * $p<0.10{ }^{* *} p<0.05{ }^{* \star *} p<0.01$

Columns (1) and (2) show the relationship between the indicators of vulnerability and the indicator for households delinquent on their debt. The probability of being delinquent is higher for FMLAI-vulnerable households than for DSIMI-vulnerable ones. Indeed, the predicted probability of delinquency is, on average, 8.3 percentage points higher for a household that is vulnerable according to the DSIMI indicator; the increase is larger and equal to 14.8 percentage points for a household vulnerable according to the FMLAl indicator. We can reject the hypothesis that the two coefficients are the same. The share of correctly predicted cases in the two regressions is about the same; however, the sensitivity is significantly higher in the regression with the indicator of vulnerability based on the FMLAI (54 per cent, compared with 30 per cent for the DSIMI). The low performance of the DSIMI reflects the fact that about 60 per cent of delinquent households have a debt service-to-income ratio below 27 per cent, as shown in Table 3 .

As the DSIMI and the FMLAI capture different vulnerable households, we construct a new indicator that takes a value of one if either the DSIMI or the FMLAI equals one and zero otherwise (Column 3). As expected, this indicator performs significantly better: about 62 per cent of delinquent households are correctly classified. The erroneously classified households are proportionally more concentrated in the upper quartiles of equalized income as neither of the two indicators explicitly takes into accounts those households, as shown in Table $2 .^{6}$

As a robustness check we drop the DSIMI's restriction on income below the median and we assume that having a debt service-to-income ratio above 30 per cent is a sufficient condition for vulnerability. We find that, with respect to the DSIMI, the shares of vulnerable households and of their debt are significantly larger, but the improvement in the number of delinquent households classified correctly is negligible.

\footnotetext{
${ }^{6}$ If we include the household controls (year, household head's education, household head's age class, area of residence, size of the municipality, gender, household size, work status), the results are qualitatively unchanged.
} 
Regardless of the indicator used, households that are predicted to be delinquent exceed the actual ones. Any vulnerability indicator thus identifies an upper bound of the risk for the financial sector stemming from households.

\section{Performance of the two indicators in predicting delinquent households}

In this section we evaluate whether the two single indicators of vulnerability are able to anticipate by two years a household's late payment. Specifically, we test whether, over a two-year horizon, vulnerable households are more likely to be delinquent than others. To this end, we restrict our sample to indebted households for which we have at least two consecutive observations; we drop the households that were delinquent both at time $t-2$ and at time $t$ to capture only the new entries into delinquency $(2,053$ households). We run the following regression:

$$
\operatorname{Pr}\left(\text { delinquency }_{t}\right)=D\left(\text { vuln }_{t-2}\right)+\varepsilon_{t}
$$

where the variable $D\left(v u l n_{t-2}\right)$ is a dummy equal to one if the household is vulnerable at time $t-2$. The results of the logit regressions are shown in Table 5.

Table 5: Logit regressions: probability of delinquency (leading indicators)

\begin{tabular}{|c|c|c|c|}
\hline & $(1)$ & (2) & (3) \\
\hline vuln DSIMI (t-2) & $\begin{array}{c}0.024272 \\
(0.02009)\end{array}$ & & \\
\hline vuln FMLAI (t-2) & & $\begin{array}{c}0.02721 \text { * } \\
(0.01931)\end{array}$ & \\
\hline vuln DSIMI (t-2) or vuln FMLAI (t-2) & & & $\begin{array}{c}0.030144 \text { ** } \\
(0.01738)\end{array}$ \\
\hline Observations & 2,051 & 2,051 & 2,051 \\
\hline$F(1,2052)$ & 2.20 & 3.01 & 4.61 \\
\hline Correctly predicted & $87.2 \%$ & $88.6 \%$ & $82.8 \%$ \\
\hline Sensitivity & $22.1 \%$ & $26.5 \%$ & $35.3 \%$ \\
\hline Specificity & $89.4 \%$ & $90.7 \%$ & $84.4 \%$ \\
\hline False + rate for true & $10.6 \%$ & $9.3 \%$ & $15.6 \%$ \\
\hline False - rate for true & $77.9 \%$ & $73.5 \%$ & $64.7 \%$ \\
\hline Average default probab. (predicted) & $3.1 \%$ & $3.1 \%$ & $3.1 \%$ \\
\hline
\end{tabular}

The table reports marginal effects. Standard errors in parentheses.

Statistical significance: * $p<0.10{ }^{* *} p<0.05{ }^{* * *} p<0.01$

The coefficient of the DSIMI is not statistically significant, while that of the FMLAI is significant at 10 per cent. However, we cannot reject the hypothesis that the two coefficients are the same. The coefficient of the combined indicator is statistically significant at 5 per cent: being vulnerable according to either the FMLAI or the DSIMI indicator increases the probability of being delinquent in the next two years by 3 
percentage points. However, in this last case the sensitivity is again quite low, as only 35 per cent of households that are actually late with debt payments are correctly predicted. ${ }^{7}$

The limited forecasting capacity of these metrics reflects two facts. First, over 30 per cent of delinquent households were not indebted two years before and so they cannot be included among the vulnerable ones. Second, more than 20 per cent of delinquent households belong to the two upper quartiles of equalized income, which are not captured by the two definitions of vulnerability, as shown in Table 2 . These two facts imply that, on average, the combination of the two indicators can anticipate by two years at most 50 per cent of delinquent households. This is an upper bound as the decision to delay debt payments may be driven by negative aggregate and idiosyncratic shocks, which are not explicitly modelled.

In conclusion, the combination of the two indicators seems to have better forecasting ability than that of the two single indicators, but it remains quite limited as only 35 per cent of the households that will delay debt payments are classified correctly. Furthermore, in line with the contemporaneous results, the total number of delinquent households is over-predicted and represents an upper bound of the prospective risk to the financial sector.

\section{Final discussion}

We have analysed two indicators of households' financial vulnerability, one based on the debt serviceto-income ratio and the other based on the financial margin. We have shown that the households identified as vulnerable on the basis of the two indicators are quite different. The second indicator identifies households that are poorer, both in income and in wealth, and have a lower amount of debt.

The share of vulnerable households over the total was slightly lower for the DSIMI than for the FMLAI in 2008 and 2010, but in the last two years the values of the two indicators have been almost identical (Figure 2.a). The amount of debt held by DSIMI-vulnerable households is, instead, significantly higher than that of FMLAI-vulnerable ones (Figure 2.b). The figures also include the share of vulnerable households according to the combined indicator (DSIMI or FMLAI) and the one-year-ahead ratio of new non-performing household loans from the Central Credit Register. Looking at the correlation between these short series, it seems that the one-year-ahead ratio of new non-performing household loans is better correlated with the share of DSIMI-vulnerable households whereas, in terms of debt, the correlation is higher with the combined indicator. However, comparing vulnerability indicators and these aggregate data requires caution because the rate of new non-performing loans is based on amounts and identifies one-year flows, whereas the vulnerability indicators are based on the number of households and represent stocks at a certain point in time.

\footnotetext{
${ }^{7}$ If we include the household controls (household head's education, household head's age class, area of residence, size of the municipality, gender, household size and work status), the coefficients are no longer statistically significant. This suggests that other variables, such as job type, capture most of the variability in the dependent variable.
} 
Figure 2: Vulnerable households and rate of new non-performing loans (percentages)

a) Share of vulnerable households

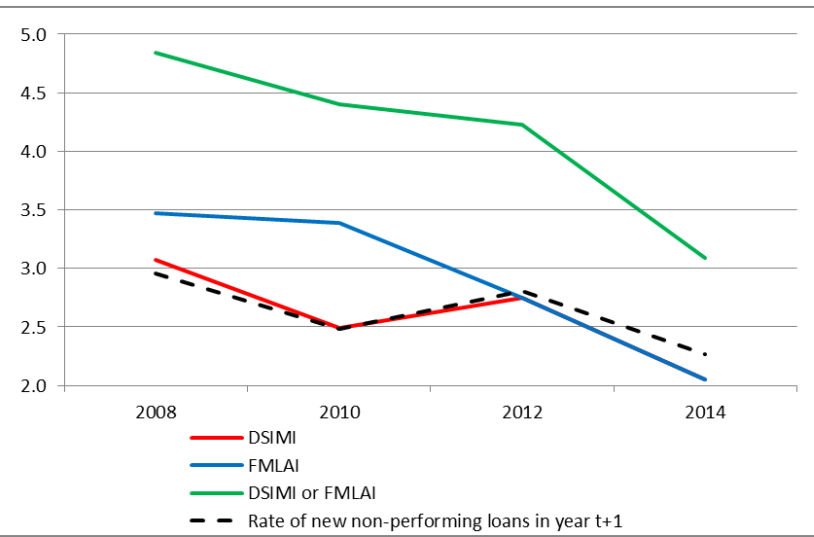

b) Share of debt held by vulnerable households

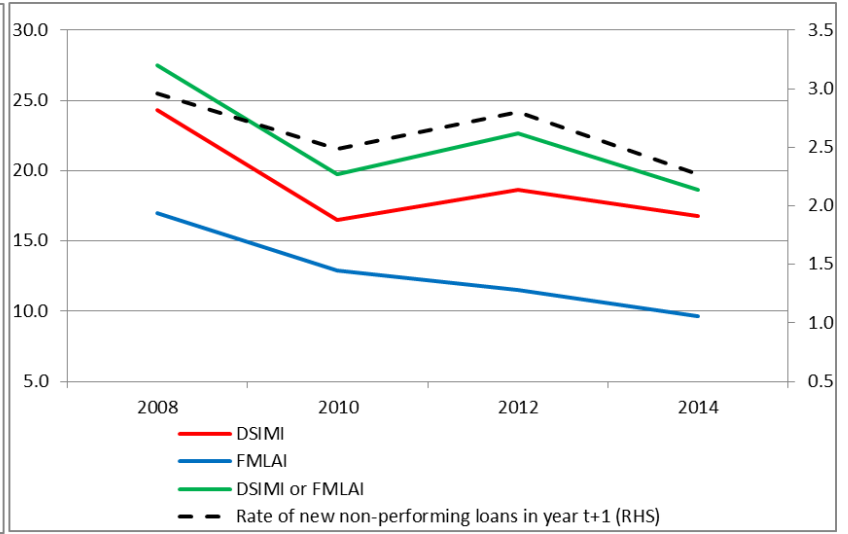

Source: Central Credit Register for the rate of new non-performing loans in year $\mathrm{t}+1$.

Note: In panel a) DSIMI, FMLAI, and DSIMI or FMLAI indicate the ratio between vulnerable households identified according to the three indicators and the total population in year t. In panel b) DSIMI, FMLAI, and DSIMI or FMLAl indicate the share of debt held by vulnerable households identified according to the three indicators in year $t$. The rate of new non-performing loans of the household sector in year $\mathrm{t}+1$ equals the one-year-ahead average of the annualized quarterly flows of adjusted non-performing loans in relation to the stock of loans at the end of the previous quarter net of adjusted non-performing loans.

From the point of view of a central bank there are pro and cons in the use of both indicators to monitor households' vulnerability.

On the one hand, the DSIMI can be more easily computed as it requires less information (disposable income and debt instalments) and its projection over time can be made by employing data available at aggregate level in a timely manner (interest rates, projections of household debt and income); for these reasons, the DSIMI provides a good level of comparability across countries and over time. On the other hand, its correlation with delinquencies at a micro level is more limited than that of the FMLAI because it does not identify as vulnerable those households with a low debt service-to-income ratio and with high equalized income. To overcome the latter problem, we carried out a robustness analysis in which having a debt service-to-income above 30 per cent is a sufficient condition for vulnerability and no restriction on income is imposed. We find that, with respect to the DSIMI, the shares of vulnerable households and of their debt are significantly larger, but the improvement in the number of delinquent households classified correctly is minor, while the correlations with the rate of new non-performing loans are lower. A periodic recalibration of the debt service-to-income ratio threshold might be necessary for a correct identification of fragile households, especially when economic conditions change. While keeping the condition of income below the median, we tested different threshold values and we can confirm that the highest correlation between delinquent and vulnerable households is for a critical value of 30 per cent.

The FMLAI, which also considers households' liquidity and basic living expenses, has a higher correlation with delinquencies at micro level. However, this indicator is far more complex to be computed and its comparability across countries and over time is limited. In fact, it displays arbitrariness in the definition of some of its components, such as basic living costs and the number of months that a stressed household can avoid delinquency by using its liquid assets. Aggregate data on these parameters are lacking 
and are difficult to compare across countries. Furthermore, a change in the economic conditions of a single country could require a modification of the parameter values, making the indicator unstable over time.

We therefore conclude that the DSIMI is a good instrument for monitoring households' vulnerability because of its simplicity, timeliness, and comparability; moreover, its use could be more advisable in the context of a financial stability assessment owing to its ability to identify the vulnerability of households with higher amounts of debt. The FMLAl can be considered a useful additional item in the set of macro-prudential tools used for an extended analysis of households' delinquencies in Italy. However, more work is needed to find an optimal instrument that correctly classifies the vast majority of delinquent households without increasing the share of those considered vulnerable too much. The low performance of the two indicators to achieve a high degree of precision in such a classification is probably due to the low indebtedness of Italian households and to the concentration of debt among the richest ones which mitigates the impact of adverse macroeconomic conditions on households' balance sheets.

Our analysis also suggests some ideas for future research. As both indicators fail to identify vulnerable households belonging to the upper quartiles of income, additional efforts could be made to better characterize these richer but vulnerable households (which in terms of debt could represent a large share of total defaults). Furthermore, total assets could be taken into account as households with negative equity are more likely to face problems with their debt payments than others. 


\section{References}

Ampudia, M., H. van Vlokhoven, and D. Żochowski (2016). 'Financial Fragility of Euro Area Households', Working paper.

Bank of Canada (2011). Financial stability review, December.

Bank of England (2014). Quarterly Bulletin 2014 Q4.

Bank of England (2016). Financial stability report no. 39 -July 2016.

Bank of Italy (2012). Financial stability report 4-2012.

Bank of Italy (2013). Financial stability report 6 - 2013.

Bank of Italy (2014). Financial stability report 2 - 2014.

Bank of Spain (2008). Economic Bulletin - October 2008.

Beer, C., and M. Schurz (2007). 'Characteristics of Household Debt in Austria: Does Household Debt Pose a Threat to Financial Stability?' Monetary Policy and the Economy, 2nd Quarter: 58-79.

Brown, M., A. Haughwout, D. Lee, and W. van der Klaauw (2010). 'The Financial Crisis at the Kitchen Table: Trends in Household Debt and Credit', Federal Reserve Bank of New York Staff Reports, 480.

Bunn, P., Johnson, R., Le Roux, J. and Rostom, M. (2015). 'Household debt and spending in the United Kingdom', Bank of England Staff Working Paper, 554.

Dey, S., R. Djoudad, and Y. Terajima (2008). 'A Tool for Assessing Financial Vulnerabilities in the Household Sector', Bank of Canada Review, (Summer): 45-54.

European Central Bank (2004). Financial stability review - December 2004.

European Central Bank (2014). 'The financial vulnerability of euro area households - Evidence from the Eurosystem's Household Finance and Consumption Survey', Monthly Bullettin November.

European Commission (2011). The measurement of extreme poverty in the European Union.

HFCN (2013). 'The Eurosystem Household Finance and Consumption Survey: Results from the First Wave', ECB Statistical Paper Series, 2

International Monetary Fund (2005). 'Household balance sheets', Global Financial Stability Report, chap. III, April 2005.

Johansson M.W., Persson M. (2006). 'Swedish households' indebtedness and ability to pay: a household level study', IFC (2006).

Karasulu, Meral (2008). 'Stress Testing Household Debt in Korea', IMF Working Paper, 08/255 (Washington, DC: International Monetary Fund).

May, O., and M. Tudela (2005). 'When Is Mortgage Indebtedness a Financial Burden to British Households? A Dynamic Probit Approach', Bank of England Working Paper, 277 (London: Bank of England).

Michelangeli, V. and M. Pietrunti (2014). 'A microsimulation model to evaluate Italian households' financial vulnerability', International Journal of Microsimulation, 7(3):53-79.

Stone M.E., (2006). 'What is housing affordability? The case for the residual income approach', Housing policy debate, 17(1).

Tiongson, E., Sugawara, N., Sulla, V., Taylor, A., Gueorguieva, A., Levin, V. and Subbarao, K. (2009). The Crisis Hits Home: Stress-Testing Households in Europe and Central Asia, Washington, DC: The World Bank. 
Vacca, V., D. Coin, A. M. Conti, L. Leva, D. Liberati, E. Manzoli, D. Marangoni, S. Mocetti, G. Saporito and L. Sironi (2013). 'L'indebitamento e la vulnerabilità finanziaria delle famiglie nelle regioni italiane', Occasional Papers (Questioni di economia e finanza), 163, Banca d'Italia.

Vatne, B.H. (2006). 'How large are the financial margins of Norwegian households? An analysis of micro data for the period 1987-2004', Norges Bank Economic Bulletin 4/06, 77: 173-180.

Zajączkowski, S. and Żochowski, D. (2007). 'The distribution and dispersion of debt burden ratios among households in Poland and its implications for financial stability', Bank for International Settlement IFC Bulletin, 26: 62-74. 